Dr. Hajdú Ferenc* - Dr. Klemensits Péter** - Sárhidai Gyula

\title{
A kínai WU-14 Dong Feng-21D nagy hatótávolságú hajó elleni ballisztikus rakéta és a csendes-óceáni erőegyensúly átalakulása
}

2 015. szeptember 3-án a második világháború befejezésének 70. évfordulóján Pekingben megrendezett katonai parádén a kínai Népi Felszabadító Hadsereg számos új haditechnikai eszközt vonultatott fel, amelyeket korábban nem láthatott a nyilvánosság. Ezek közé tartozik, a Dong Feng 21D „hordozógyilkos” elnevezésű, hajó elleni ballisztikus rakéta is, ${ }^{1}$ amely a szakértők egybehangzó véleménye alapján az amerikai repülőgép-hordozók elsülylyesztésére is alkalmas. Továbbfejlesztett változata a Dong Feng 26-os pedig elsősorban megnövekedett hatótávolsága miatt jelenthet komoly veszélyt az Egyesült Államok flottája számára. Az utóbbi években Nyugaton nagy nyilvánosságot kapott kínai hajó elleni ballisztikus rakéták alapvetően az elrettentést szolgálják, háborús környezetben kifejtett feltételezett hatékonyságukat illetően viszont megoszlanak a vélemények. Vitathatatlan azonban, hogy a csendes-óceáni erőegyensúly folyamatosan Kína javára tolódik el, ez pedig az Egyesült Államok részéről is választ kíván.

\section{1. ábra DF-21C rakéta (WS-2400) hordozó jármúvön}

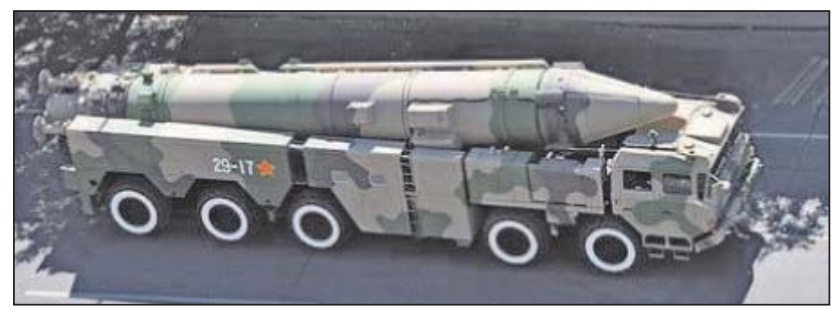

ÖSSZEFOGLALÁS: A tanulmány a kínai Népi Felszabadító Hadsereg olyan új haditechnikai eszközeivel foglalkozik, mint a Dong Feng 21D „,hordozó gyilkos” elnevezésű hajó elleni ballisztikus rakéta, amely az amerikai repülőgéphordozók elsüllyesztésére is alkalmas. Bemutatásra kerül ennek továbbfejlesztett változata is, a nagyobb hatótávolságú Dong Feng 26 rakéta. Az új eszközök megjelenése miatt a Csendes-óceán nyugati felében uralkodó hadászati viszonyok várhatóan átalakulnak majd.

KULCSSZAVAK: Dong Feng, ballisztikus rakéta, robotrepülőgép, repülőgéphordozó, kínai Népi Felszabadító Hadsereg, Egyesült Államok

\section{A „HORDOZÓGYILKOS” Dong FEng 21D}

A Kínai Népköztársaság már az 1970-es években érdeklődést mutatott a hajó elleni rakéták kifejlesztése iránt, de a hidegháború végéig jelentős eredményt ezen a téren nem tudott felmutatni. Az 1995-96-os harmadik taiwaniszorosbeli válság után ${ }^{2}$ Peking fokozta az erőfeszítéseket, amelynek következtében a 2000-es években már a legmodernebb ballisztikus rakétákkal kezdődtek meg a kísérletek. $^{3}$

A WU-14-es Dong Feng-21D (DF-21D) NATO kódnevén CSS-5 Mod 5-ös nagy hatótávolságú hajó elleni ballisztikus rakéta a Dong Feng (keleti szél) interkontinentális ballisztikus rakéták családjába tartozik és a DF-21-es (CSS5-ös) közép-hatótávolságú ballisztikus rakéta haditengerészeti célpontok ellen kifejlesztett variánsának számít. Az amerikai források szerint a rakéta 2010-ben érte el a kezdeti hadműveleti képességét, 2014 és 2016 között pedig 5 alkalommal próbálták ki, amelyek közül csupán a második próbarepülés volt sikertelen. ${ }^{4}$ Igazi jelentősége, hogy a DF-21D a világon az első olyan komplex fegyverrendszer, amely a szárazföldről indítva képes a mozgásban lévő repülőgép-hordozók megsemmisítésére.

A 2015-ben már biztosan hadrendben lévő hiperszonikus rakéta hatótávolsága a becslések szerint 1500 és 2000 km közé tehető. ${ }^{5}$ Ezt a kínai források és a Pentagon is elismerik. Hosszúsága 12,3 m, átmérője 1,4 m, tömege pedig $15200 \mathrm{~kg} .^{6}$

A szilárd tüzelőanyaggal működő, kétlépcsős rakétatest egyetlen konvencionális töltettel szerelt robbanófejet hor-

ABSTRACT: The study deals with such new military technology of the Chinese People's Liberation Army such as the anti-ship ballistic missile named Dong Feng 21D (carrier killer) capable of sinking US aircraft carriers, too. There will also be described its developed version, the missile Dong Feng 26 with longer range. Because of appearance of new weapons, a change in strategic relations existing in the Western side of the Pacific is expected.

KEY WORDS: Dong Feng, ballistic missile, cruise missile, aircraft carrier, the Chinese People's Liberation Army, the United States

* MH Logisztikai Központ Kutatás Fejlesztési, Tudományos és Szabványosítási Osztály osztályvezető, Nemzeti Közszolgálati Egyetem, KMDI oktató HDF Logistic Center, Departmetn for Research and Technology, Science and Standardization, chief. National University of Public Service, instructor KMDI E-mail: Hajdu.Ferenc@hm.gov.hu ORCID: 0000-0003-0449-7678

** Pallas Athéné Geopolitikai Alapítvány, Dél- Délkelet-Ázsia Kutatóintézet, szenior kutató. Pallas Athéné Geopolitical Institute of South- Southeast Asia, Senior Researcher peterklemensits@yahoo.com ORCID: 0000-0003-2907-9130 


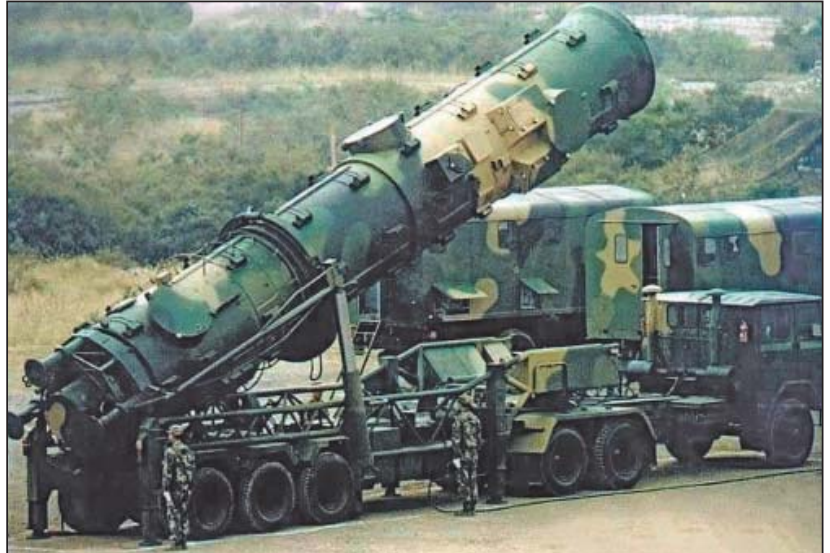

2. ábra. A korai CSS-5 DF 21-es indító helyzetbe állítás közben

doz, amelynek az indítására egy 5 tengelyes mobil indítóállvány szolgál. Indítást követően a célravezetésről a legmodernebb radar- és műholdrendszerek, illetve pilótanélküli repülőgépek által továbbított információk gondoskodnak. A manőverezni képes robbanófej a hangsebesség tízszeresével (12 $000 \mathrm{~km} / \mathrm{h}$ ) közelít a célpontja felé, ezért az elfogása a hagyományos rakétavédelem számára szinte lehetetlen. ${ }^{7}$ (Mivel a legmodernebb repülőgép-hordozók védelmi rendszere ellen élesben soha nem próbálták ki, ezért többnyire a rendelkezésre álló nyilvános információk alapján jutottak az elemzők erre a következtetésre.)

A 2015-ben az átszervezések után önálló haderőnemmé vált rakétaerő kötelékében jelenleg 6 hajó elleni rakétadan-

\section{3. ábra. DF-21C rakéta hordozójárművön}

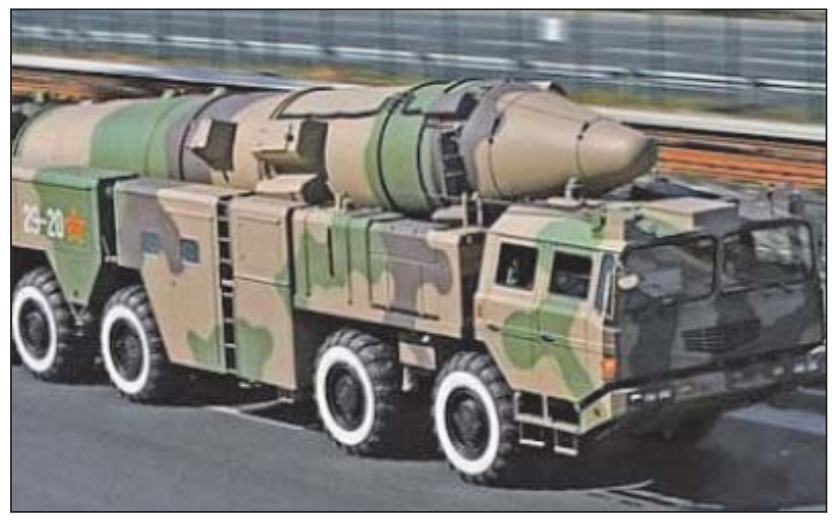

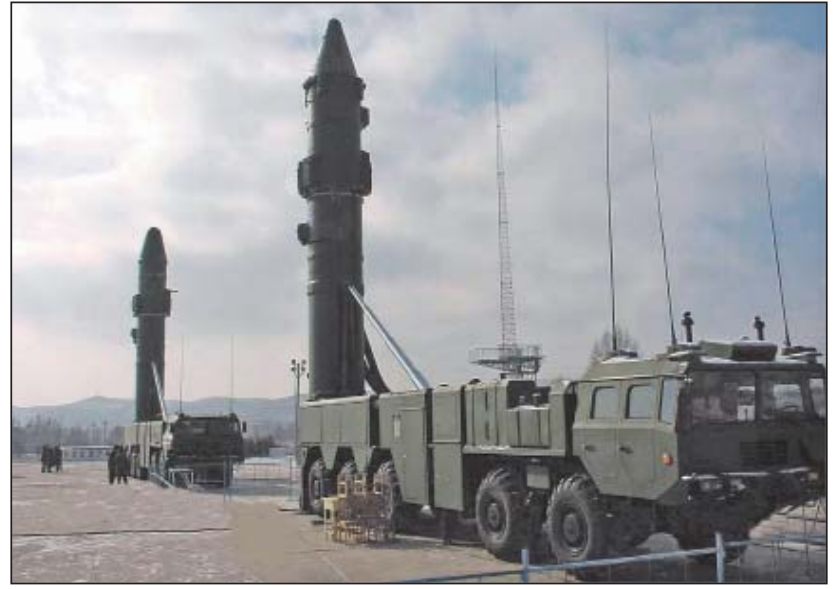

4. ábra. A DF-21C rakéták a TEL (Transporter Erector Launcher) jármúvön

dár teljesít szolgálatot, amelyek mindegyike 24-32 db DF-21D rakéta indítására képes indítóállvánnyal rendelkezik, így elméletben - a hadgyakorlatokat is figyelembe véve egyszerre akár 168-224 robbanófejet is bevethetnek. ${ }^{8}$

\section{A Dong Feng 26-oS ÉS A hAJó ELLENI ROBOTREPÜLŐGÉPEK}

A 2015 szeptemberében megtartott katonai díszszemlén mutatták be a nyilvánosságnak először a DF-21D továbbfejlesztett változatát a Dong Feng 26-os közép hatótávolságú ballisztikus rakétát, amely hajó elleni ballisztikus rakéta változatban is rendelkezésre áll. A hivatalos kínai álláspont szerint az eszköz közepes és nagy távolságú szárazföldi precíziós csapásmérés mellett, a „nagy és közepes méretű tengeri célpontok" ellen is hatásos. ${ }^{9} \mathrm{~A}$ rakéta kétféle nukleáris és több féle konvencionális töltettel felszerelt robbanófej hordozására képes, továbbá hajó elleni hiperszonikus manőverező robbanófejjel is indítható. Főbb müszaki paraméterei a következők: hosszúsága 14 m, átmérője 1,4 m, tömege 20000 kg. Legfőképpen azonban megnövelt hatótávolsága miatt került a figyelem középpontjába: a kínai források szerint maximális hatótávolsága $5000 \mathrm{~km}$, de a nyugati szakértők becslései alapján reálisan ez 3000-4000 km körül lehet. ${ }^{10}$ Mindazonáltal - a repülőgép-hordozókkal egyetemben - az amerikai bázisokra nézve (pl. Guam) komoly veszélyt jelenthet, ezért is kapta a "Guam gyilkos" elnevezést.

A Pentagon legfrissebb jelentése ${ }^{11}$ csupán futólag említi a DF-26-os rakéta hajó ellen bevethető változatát és való-

1. táblázat. A DF-21-es rakétacsalád jelenleg ismert adatai

\begin{tabular}{|l|c|c|c|c|c|}
\hline \multicolumn{1}{|c|}{ Típus } & DF-21 & DF-21A & DF-21C & DF-21D & DF-26 \\
\hline NATO-kód & CSS-5 & CSS-5Mod1 & CSS-5Mod3 & CSS-5Mod4 & n.a. \\
\hline Robbanófej & $\begin{array}{c}1 \mathrm{db} \\
\text { vagy 5-6 db } \\
\text { nukleáris }(600 \mathrm{~kg})\end{array}$ & $\begin{array}{c}1 \mathrm{db} \text { biztos } \\
\text { lehet 2-3 db }\end{array}$ & n.a. & n.a. & n.a. \\
\hline $\begin{array}{l}\text { Hatás } \\
\text { Szórás (CEP) }\end{array}$ & $\begin{array}{c}500 \mathrm{kt} \\
300-400 \mathrm{~m}\end{array}$ & $\begin{array}{c}\text { n.a. } \\
100-300 \mathrm{~m}\end{array}$ & $\begin{array}{c}\text { n.a } \\
10-50 \mathrm{~m}\end{array}$ & $\begin{array}{c}\text { n.a. } \\
10-50 \mathrm{~m}\end{array}$ & $\begin{array}{c}\text { n.a. } \\
10-15 \mathrm{~m}\end{array}$ \\
\hline Telepítve & 1991 & 1996 & $2006-2010$ & 2009 & $2016 \mathrm{kísérleti}$ \\
\hline Hatótávolság (km) & 1770 & 2150 & 1700 & $\begin{array}{c}2450 \\
(1666-2778)\end{array}$ & $3000-4000$ \\
\hline Sebesség (Mach) & $\mathrm{M} 10$ & $\mathrm{M} 12$ & $\mathrm{M} 10$ & $\mathrm{M} 10$ & $\mathrm{~kb} . \mathrm{M} 12$ \\
\hline
\end{tabular}

CEP: Circular Error Probable (várható körkörös hiba) 


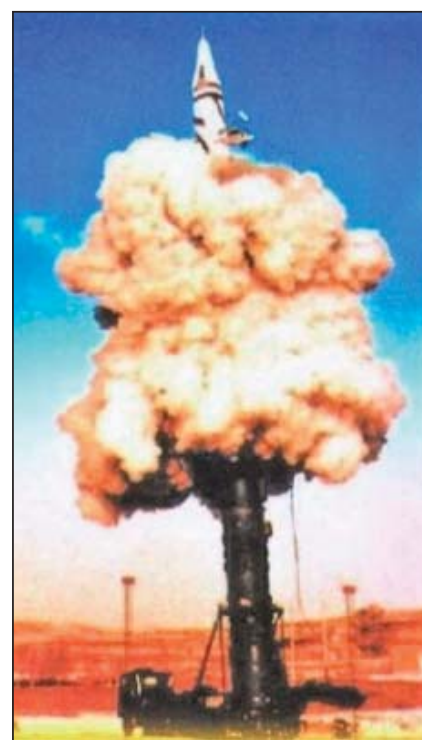

5. ábra. Egy DF-21A rakéta próbaindítása még a régi konténerből

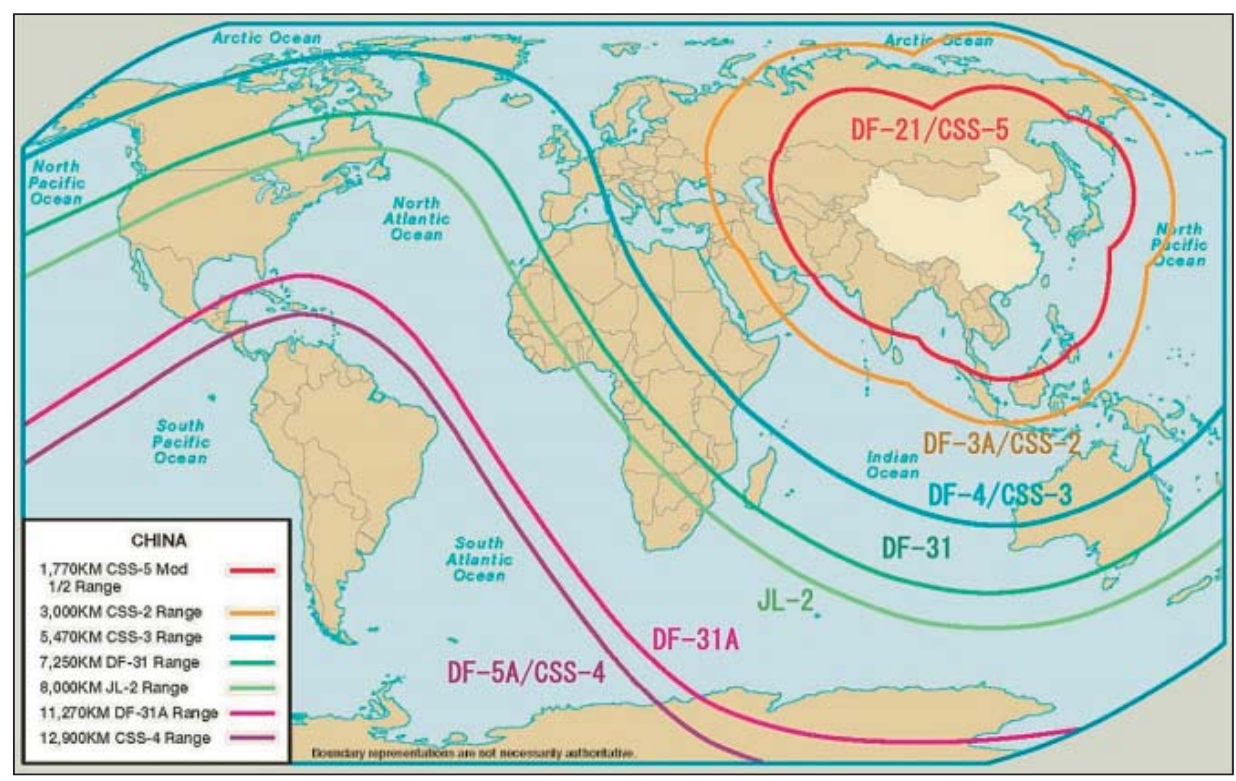

7. ábra. A jelenleg alkalmazott kínai ballisztikus rakéták hatótávolsága a földfelszín vetületén ábrázolva jában kevés információval rendelkezünk róla. A rakéta rendszeresítése már minden bizonnyal megtörtént, de hogy mely alakulatok pontosan hány indítóállvánnyal, rakétatesttel, robbanófejjel stb. rendelkeznek, vagyis háborús szituációban mekkora veszélyt jelentenének az ellenfélre nézve, szinte lehetetlen megbecsülni. ${ }^{12}$

Van egyéb meggondolás is. Műszakilag nehézség nélkül építhető a DF-26-oshoz hasonló felépítésű rakéta, de három fokozattal és a Phersing-Il típusénak megfelelő önvezérlő, manőverező robbanófejjel. Ennek hatótávolsága elérheti a 6-7000 km-t, és képes több zavaró „mű célpont” szállítására is.

Ennek lehetősége ma már adott, csak pénz és kapacitás kérdése a megvalósítás. Ezek a Csendes-óceán 80\%-át belőhetik és bevethetőek az Indiai-óceán K-i térsége ellen is. Az ilyen típusú rakéták rendszerbe állítása az USA teljes haditengerészeti stratégiájának és feladatkörének átalakítását kívánná. Az amerikai doktrínákkal kapcsolatos viták jelenleg zajlanak, a katonai-műszaki realitások függvényében.

A hajó elleni ballisztikus rakéták mellett az USA haditengerészetének vezetését egyre nagyobb mértékben ag-

6. ábra. A hajó elleni változat pályájának sematikus rajza, ezen a II. fokozat önkereső fejrészú és a leszálló ágon módosítja a röppályáját

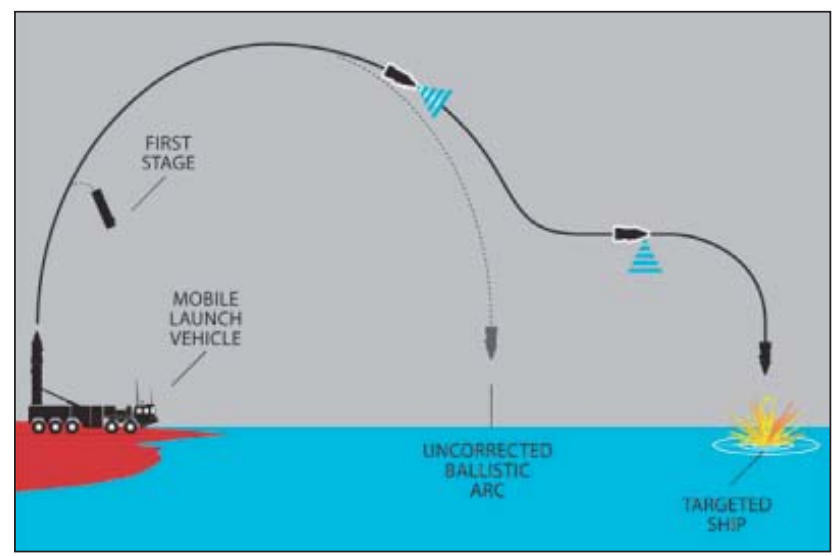

gasztja a kínai hajó elleni „cirkálórakéták” (robotrepülőgépek) legújabb generációjának a megjelenése is. A 2015ben már rendszeresített YJ-12-es hajó elleni cirkálórakéta hatótávolsága 250-400km-re tehető, 205-500kg súlyú robbanófeje pedig 2-4 Mach sebességgel tart a célpontja felé. ${ }^{13}$ Vadászgépekről, vadászbombázókról és bombázókról egyaránt indítható. Nagy sebessége miatt elfogása különösen nehéz és a feltételezések szerint egyetlen robbanófej becsapódása megsemmisíthet egy Aegis osztályú cirkálót, kettő pedig egy hordozót is elsüllyeszthet. Észlelése és elfogása helyett az USA haditengerészete döntően az indító-repülőgépek felderítését és megsemmisítését tartja célravezetőbbnek.

Szintén a közelmúltban lépett hadrendbe a YJ-18-as szárazföldi támadó „cirkálórakéta” (robotrepülőgép) és hajó elleni „cirkálórakéta” (robotrepülőgép), amelynek hatótávolsága 220-540 km, a robbanófej tömege 140-300 kg, végsebessége pedig 2,5-3 Mach. ${ }^{14}$ Sebessége és kanyargós röppályája miatt az elfogása komoly akadályokba ütközik. Alapvetően rombolókról és tengeralattjárókról indítható. Radarromboló funkciója következtében - egyes feltételezések szerint - a hajótól 50 méterre felrobbanva egy Aegis osztályú cirkáló elektronikai rendszerének 60\%-át teheti tönkre. ${ }^{15}$

A legújabb cirkálórakéta típusról a YJ-100-asról még kevés a pontos információ, de $800 \mathrm{~km}$-es hatósugarával és alacsony röppályájával mindenféleképpen veszélyt jelent-

8. ábra. A hajók ellen szánt DF-21C rakéták a szállító-indító járművön a pekingi díszszemlén

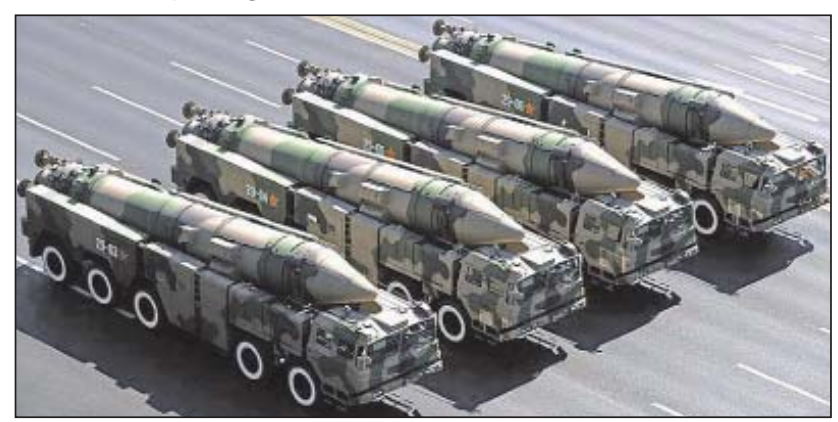




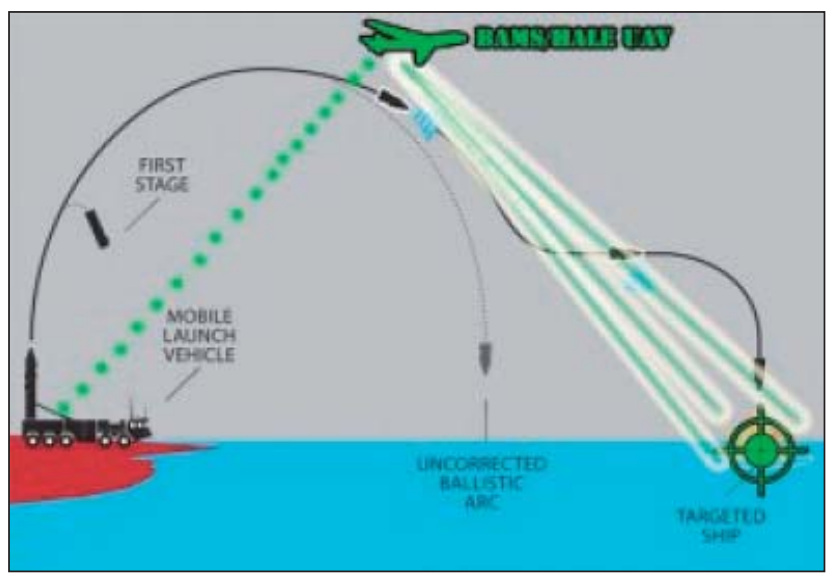

9. ábra. Másik kínai vázlat a rakéta II. fokozatának müködéséről, amely egy felderítőgép által lokátorral megvilágított cél visszaverődő jeleire vezéreli a robbanófejet

het a jövőben az amerikai flottára nézve. A Type 055 rakétás rombolót már valószínűleg ezzel a rakéta típussal fegyverezték fel. ${ }^{16}$

\section{A STRATÉGIAI EGYENSÚLY ELTOLÓdÁSA}

2013 decembere és 2015 júniusa között Kína 11,7km² korallzátonyt töltött fel és alakított át mesterséges szigetekké a Dél-kínai-tengeren található vitatott hovatartozású Spratley-szigeteken, 2015 második felében pedig a Paracel-szigeteken folytatta a munkálatokat. ${ }^{17}$ A dél-kínaitengeri mesterséges szigetek létrehozása és katonai célú hasznosítása mindennél jobban érzékelteti Kína megváltozott - a korábbiakhoz képest agresszívabb - külpolitikai/ biztonsági stratégiáját, amelyben a Dél-kínai-tenger térsége feletti ellenőrzés megszerzése és az USA kiszorítása a régióból prioritást élvez, ennek érdekében pedig Peking szakított korábbi kooperációra hajlandó magatartásával.

A kínai haditengerészet érvényben lévő „nyílt tengeri védelem" doktrínája egyértelműen a védvonalak kiterjesztését írja elő, amelynek hatására a közeljövőben az első szigetláncig kell hadműveletekre felkészülnie a flottának. Hosszú távon már a második szigetláncot elérő aktív tengerészeti jelenlét a cél, amely az USA csendes-óceáni befolyásának visszaszorítását is feltételezi a 21. század közepén. ${ }^{18}$

Mindezen célok elérése érdekében Kína katonai potenciálja számottevő fejlődésen ment keresztül az utóbbi időben, amely elsősorban a „hozzáférést gátló / területmegtagadó" (A2/AD) ${ }^{19}$ képességek megerősödésében nyilvánul meg. Ez a stratégia alapvetően a repülőgép-hordozók, nukleáris meghajtású támadó tengeralattjárók, rakétás cirkálók és rombolók rendszeresítése mellett nagy hatótávolságú rakétavédelmi rendszerek (hajó elleni ballisztikus rakéták és cirkálórakéták) hadrendbe állításával kívánja elejét venni ellenfele aktív katonai jelenlétének az adott régióban.

Amint azt az 1995-96-os harmadik taiwani-szorosbeli válság is bizonyította, a múltban az Egyesült Államok tetszése szerint küldhetett flottát a kínai partokhoz, ha ellenfelét együttműködésre kívánta szorítani, vagy csupán érzékeltetni megkérdőjelezhetetlen globális dominanciáját. Az elmúlt 20 év során az erőviszonyok terén - látszatra - nem sok változás történt, valójában azonban Kína felemelkedésével és az amerikai befolyás csökkenésével párhuzamosan a hatalmi átrendeződés már megkezdődött. A szigetfeltöltések pedig mindenki számára nyilvánvalóvá tették a hadászati környezet megváltozását.
Az USA - katonai értelemben is - igyekszik erre méltó választ adni, az „újra-egyensúlyozás” koncepciónak ${ }^{20}$ megfelelően támogatni szövetségeseit és demonstrálni erejét Kínával szemben. A Spratley-szigeteki építkezésekre reagálva 2015 októberében, jelezvén hogy nem ismeri el a status quo megváltoztatását, az amerikai haditengerészet USS LASSEN rakétás rombolója, Kína tiltakozása ellenére 12 mérföldnél közelebb hajózott az egyik „újonnan épített” szigethez. 2016 januárjában pedig a USS CURTIS WILBUR rakétás romboló tette ugyanezt a Paracel-szigetekhez tartozó Triton-sziget közelében. Március elején az amerikai vezetés a USS JOHN STENNIS repülőgép-hordozó vezetésével egy csapásmérő csoportot küldött a térségbe, nem törődve Kína rosszallásával. Végül májusban a USS WILLIAM P. LAWRENCE rakétás romboló közelítette meg a Spratley-szigetek egyik feltöltött zátonyát.

Háborús helyzetben azonban már kétséges, hogy az amerikai repülőgép-hordozók délkelet-ázsiai alkalmazása mennyire lenne bölcs lépés és ezzel az amerikai katonai vezetés is tisztában van. A csendes-óceáni erőegyensúly eltolódása láthatóan nem kerülte el az amerikai szakértők figyelmét sem, sőt egy jelentős és elhúzódó diskurzust indított el, amelynek a lényege, hogy az USA miként fogja tudni fenntartani katonai dominanciáját a térségben, és ennek érdekében - különösen a haditengerészet fejlesztését tekintve - milyen nagy horderejü döntések meghozatalára lesz hajlandó.

\section{A REPÜLÖGÉP-HORDOZÓK JöVÖJE}

Hogy a kínai hajó elleni rakéták kifejlesztésének mekkora a jelentősége, arról sokat elárul az amerikai katonai szakértők vélekedése, akik közül néhányan a hadviselés forradalmának meghatározó fejezetei közé sorolják, mivel véget vet a repülőgép-hordozókat övező legyőzhetetlenség mítoszának és talán a megváltozott körülmények miatt azok elavultságát is bizonyítja. Peking szerint a DF-21D hajó elleni ballisztikus rakéta egy igazi „orgyilkos buzogányfegyvere", ${ }^{21}$ másképpen fogalmazva, igazi titkos fegyver lehet az aszimmetrikus tengeri hadviselésben.

Az amerikai hadvezetés nagy horderejű döntés előtt áll, amikor a költségvetési megszorítások ellenére új repülőgép-hordozók rendszeresítését tervezi, miközben azok Kínával szembeni hatékonysága sokak szerint már megkérdőjelezhető. 2012-ben a haditengerészet magas rangú tisztjei még úgy érveltek, hogy az új GERALD F. FORD osztályú hordozók mindenképpen megérik a rájuk fordított költségeket, hiszen hosszú távon biztosítani fogják az amerikai katonai jelenlétet a Föld bármely pontján, és érvényre is juttatják a stratégiai elképzeléseket.22

Egyesek viszont úgy érvelnek, hogy az USA kormánya nem engedheti meg magának, hogy 13,5 mrd dollárért egyetlen hajót vásároljon, amely a legmodernebb felszereltsége ellenére sem lenne képes biztonsággal ellátni feladatát a Dong Feng 21D rakéta 900 mérföldes (1448km) hatótávolságán belül. ${ }^{23}$ Jerry Hendrix kapitány a Center for New American Society kutatója szerint ráadásul a legújabb hordozók hatékonysága - a fedélzetén található légierőt nézve - csupán 33\%-kal nőtt a régebbi típusokhoz képest, miközben a költségek 94\%-kal emelkedtek. Ráadásul, 2013-as árfolyamon számolva, ezen a költségen a legóvatosabb becslések szerint is Kína több mint 1200 db Dong Feng rakétát képes előállítani, amelyek közül akár egy is okozhatja egy hordozó megsemmisülését. ${ }^{24}$

Éppen ezért levonhatjuk a következtetést, hogy a hordozók alkalmazásához köthető érvényben lévő doktrína hala- 


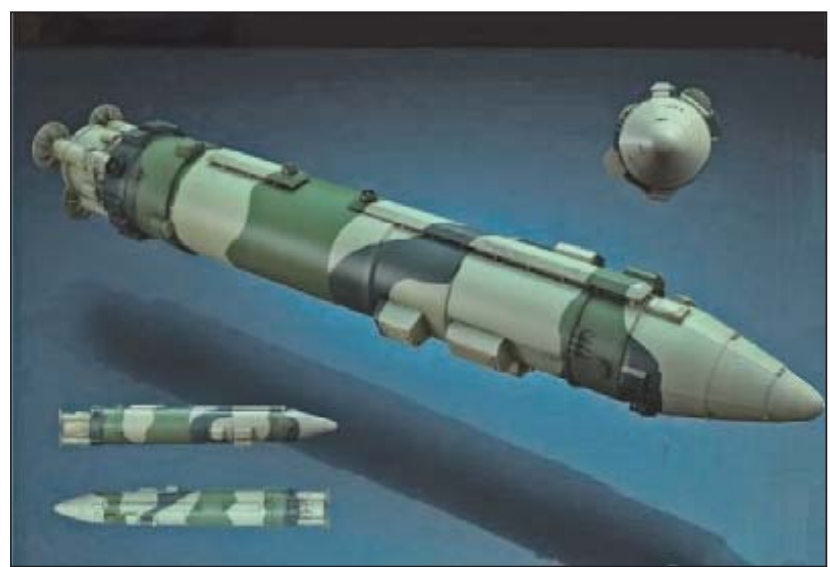

10. ábra. A DF-21D nézeti rajzai kínai forrás szerint

déktalanul változtatásra szorul, ezzel együtt pedig a technikai fejlesztések és beszerzések területén is teljesen új prioritásokat kell megfogalmazni. Hendrix szerint az amerikai haditengerészet egyik fő problémája, hogy nem rendelkezik nagy hatótávolságú harci repülőgépekkel, ezt a problémát pedig a legújabb generációs, lopakodó F-35C tervezett szolgálatba állítása sem fogja megoldani a közeljövőben. Az F-35C program mellett inkább a nagy hatótávolságú harci drónok kifejlesztésére kellene koncentrálni. ${ }^{25}$

Összességében Hendrix úgy látja, hogy a legújabb FORD osztályú hordozók helyett a 21 . század közepére több, kisebb kb. 5 mrd dollárba kerülő könnyű hordozókat kell hadrendbe álítani, amelyek a kínai hajó elleni rakéták hatótávolságán túl is alkalmazhatóak lennének, ugyanis a legfőbb erejüket a rövid hatósugarú vadászgépek helyett

11. ábra. Kínai sematikus vázlat a C-602-es, C-602A, C-605-ös robotrepülögépek, a DF-21D ballisztikus rakéták és megfigyelő repülőgépek alkalmazásairól

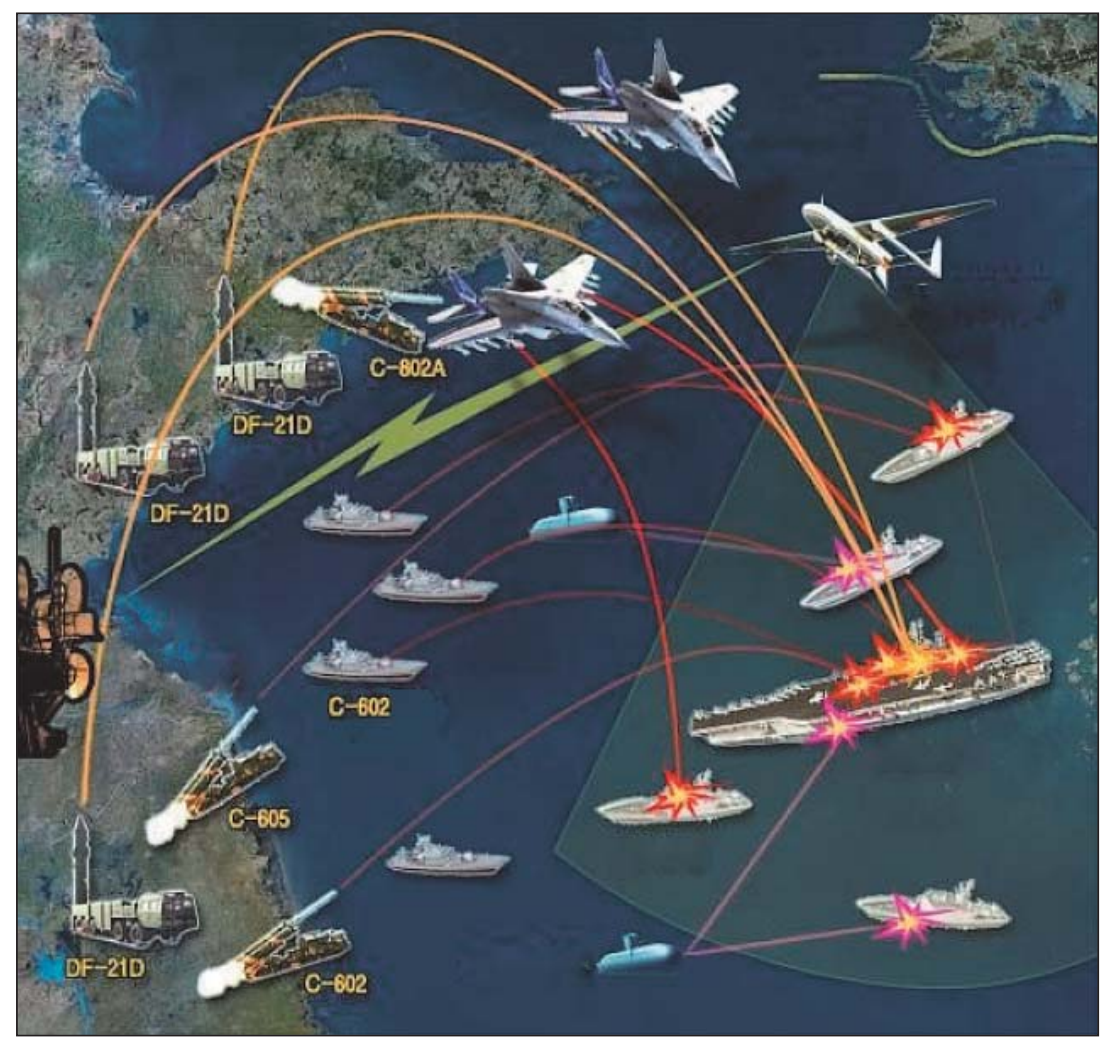

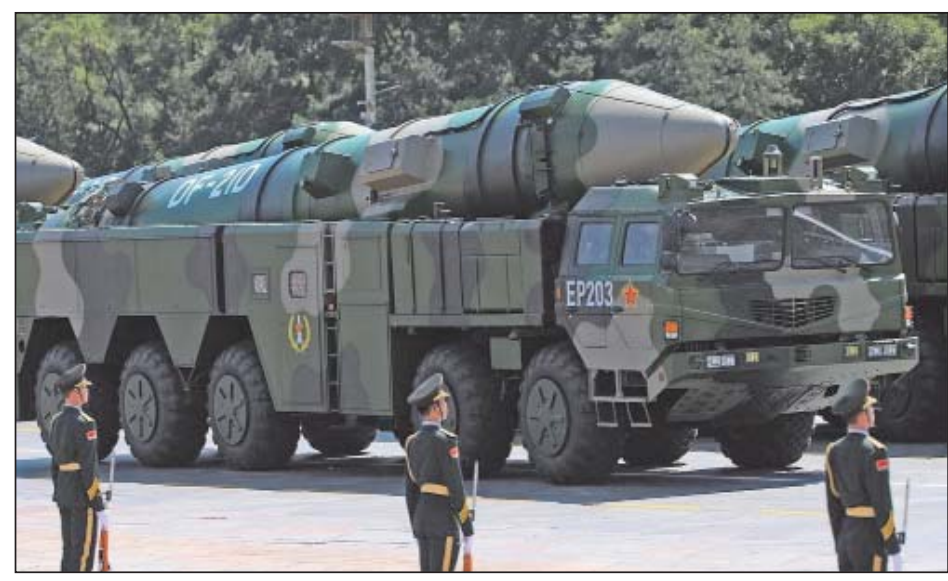

12. ábra. A DF-21D rakéták felvonulása a 2015-ös díszszemlén. A kevés eset egyike, hogy a rakéta típusa fel van festve a palástra

nagy hatótávolságú és nehézfegyverzetű harci drónok jelentenék. ${ }^{26}$

Bizonyos számítások szerint a repülőgép-hordozóktól eltekintve a rakétavédelmet biztosító Aegis rombolók sem tűnnek igazán költséghatékony megoldásnak. Egy romboló $90 \mathrm{db}$ Standard-3 Block 1B rakétával szerelhető fel, amelyek egyenkénti költsége 10 millió dollár. Ennek ellenére reális az esélye annak, hogy egy tömeges rakétatámadás esetén képtelenek lennének a hordozócsoport védelmére, és a 2 milliárd dollár értékű rakétás romboló elvesztése is elképzelhető lenne. ${ }^{27}$

A Hudson Institute szakembereinek jelentése ezzel szemben kitart a szuperhordozók relevanciája mellett, mivel azok árérték arányosan messze pótolhatatlan erőkivetítési képességgel rendelkeznek és önálló, mozgó légibázisoknak tekinthetőek. Amint azt a jelentés megállapítja, a nagy hatótávolságú repülőgépek hiánya valóban problémát jelent, de ezek pótlására, illetve a DF-21D-hez hasonló rakéták elleni védelem kifejlesztésére még bőven van ideje az amerikai kormányzatnak. Ennek keretében pedig a dokumentum az F-35C nagyobb teljesítményű hajtóművel való gyártását javasolja, így növelve a hatótávolságát és kerülve a harci drónokra való hagyatkozást. ${ }^{28}$

A haditengerészet vezetése kitart azon álláspontja mellett, hogy a repülőgép-hordozó az amerikai globális katonai jelenlét legfőbb szimbóluma, még hosszú éveken keresztül a tengeri hadviselés legfontosabb eszköze marad és a folyamatos fejlesztéseknek köszönhetően a modern rakétavédelmi rendszerek révén Kína korántsem jelent legyőzhetetlen ellenfelet a flotta számára. ${ }^{29} \mathrm{~A}$ DF-21D és a DF-26-os, valamint a hajó elleni cirkáló rakéták elleni konkrét védekezést tekintve, azt a Pentagon is elismeri, hogy ezeknek a nagy sebességű manőverező robbanófejeknek az elfogása nehezen kivitelezhető, ezért a rakéta komplikált „ölési láncának” a megszakítására kell koncentrálni. Mivel a robbanófej célba jutásához a műhol- 


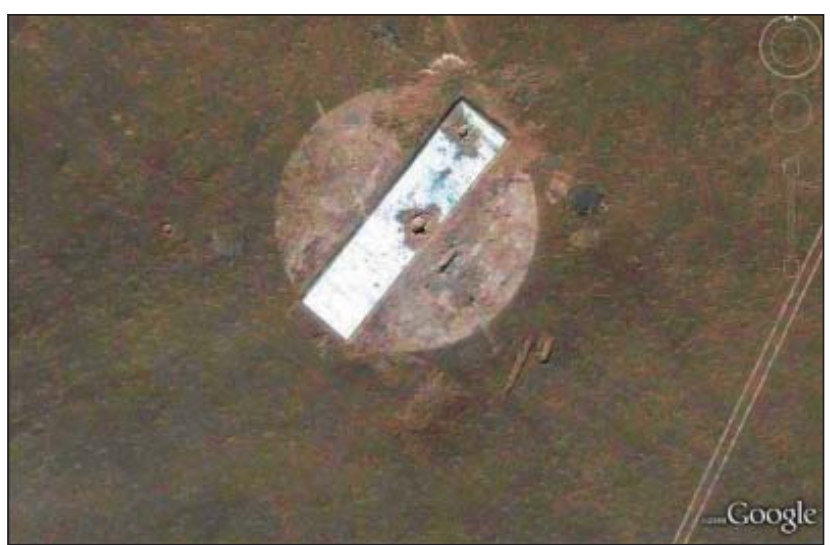

13. ábra. A Góbi-sivatagban épített célpont, DF-21-esek találati pontosságának ellenőrzésére. Felirata szerint 2009-ben készült egy polgári Föld-megfigyelő múholdról. A fehér téglalap egy NIMITZ osztályú repülőgép-hordozó mérete (Google)

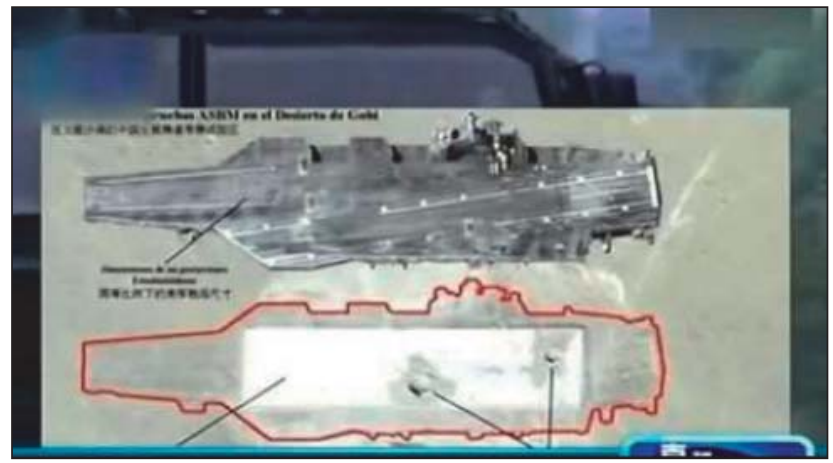

14. ábra. Kínai rajz a müholdképpel összemontírozott hordozóról, valós méretben. A két telitalálat elegendő a hajó elsüllyesztéséhez

dak, a radarok, a parancsnokság és az indítórendszerek tökéletes egyidejü kommunikációjára van szükség, így a kiberhadviselés eszközeivel, vagy az elektronikus támadásokat követő kinetikus eszközök igénybevételével indított ellencsapással a folyamat jó eséllyel megszakítható. John Richardson tengernagy a haditengerészet hadmüveleti főnöke ezért még 2016 nyarán is optimistán nyilatkozott az amerikai hordozók és a haditengerészeti légierő jövőjéről, miközben kétségbe vonta Kína A2/AD képességeit. ${ }^{30}$

Az amerikai katonai vezetők továbbra is bíznak a „légitengeri ütközet" ${ }^{11}$ doktrína eredményességében, amely a légierő és a haditengerészet legmodernebb képességeinek szoros összehangolását jelenti, miközben nagy hangsúlyt fektet a kínai rakétarendszerek elleni preventív csapás végrehajtására. Stratégiai értelemben pedig bizonyára arról sem feledkeztek meg, hogy Kína részéről egy amerikai hordozó elleni rakétatámadás gyorsan a konfliktus eszkalációjához vezethetne, amely már a rendelkezésre álló nukleáris arzenál egy részének bevetését is szükségessé tenné, ezt pedig Peking biztosan nem kockáztatná meg. ${ }^{32}$

\section{A FLOTTA ALKALMAZÁSI PROBLÉMÁl}

Az amerikai tengeri stratégia az 1950-es évek óta a „harci csoport” („,battle group”) nevű stratégiai egységekre épül. Eszerint 1-2 db repülőhordozó, 1-2 db légvédelmi cirkáló,

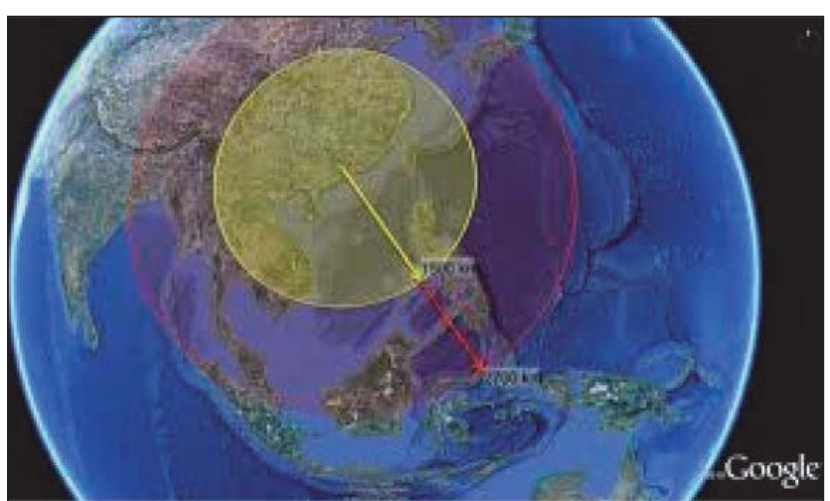

15. ábra. A rakéta hatótávolsága földgömbön ábrázolva.

Sárga kör, ha Kína belső területéről indítják, piros vonal, ha a partvidékről indul (Google)

4-8 db részben rakétás torpedóromboló, 2-3 db tengeralattjáró-elhárító fregatt, 1-2 db tartályhajó és 1-2 db ellátó hajó alkot egy harci csoportot. Két-három harci csoport egybefogva alkot egy flottát, ekkor már parancsnoki és távközlési hajó is jelen van. A csatahajók kivonása után tüzérségi kapacitásuk nem maradt, így szárazföldi, vagy vízi célpontok ellen, csak a hordozók repülőgépeit vethették be, de ez sokszor nem lehet elegendő.

Ha a rakétaveszély 4000 km-re tartja a köteléket ellenséges partoktól, repülőgépeik nem támadhatnak érdemben szárazföldi célokat, erre nincs elég üzemanyaguk.

Nagyobb számú kínai rakéta esetén a nagy hajóegységek, de még a cirkálók sem működhetnek a Hawai szigetektől nyugatra eső vizeken, konfliktus esetén, mert túl nagy a kockázat. Lehet, hogy ez a kínai stratégiai cél - kiszorítani az USA-t a Csendes-óceán nyugati feléről.

Realitás lett, hogy 2 db rakéta telitalálattal a 13,5 mrd dolláros hordozó- és 6 mrd dolláros repülőgép-készlete egyszerre veszik el. Egy új hajó építése jelenleg 10 év, és mindössze egyetlen üzem alkalmas a FORD osztályú hajók gyártására.

Már tudjuk, hogy Kína 2 db új, a LIAO NING-hez hasonló felépítésű, de korszerủbb egységet épít, ezeket 2017 végén át lehet adni. Nem ismert semmilyen adat, hogy mi a KN flotta célja három hordozóval.

\section{A KÖVETKEZMÉNYEK}

A fentiekben vázolt dilemma már napjainkban is a hadászati viszonyok átalakulásáról tanúskodik a Csendes-óceán nyugati felében, amelynek jövőbeli biztonságpolitikai következményei még markánsabbak. Ha elfogadjuk Hendrix kapitány érvelését, amelynek értelmében, ha csupán $10 \%$ reális esélye mutatkozik egy hordozó elvesztésének, akkor a hadvezetés már nem kockáztatná meg a bevetését a beláthatatlan politikai következményektől tartva, ${ }^{33}$ megérthetjük, hogy néhány év múlva - jelen tendencia mellett - az USA haditengerészete már nem lesz képes háborítatlanul hadműveleteket folytatni és uralni a Dél-kínai-tengert. A kínai szigetfeltöltések és a hajó elleni ballisztikus rakéták rendszeresítése tehát egy új korszak eljövetelét jelzik Délkelet-Ázsiában, amelynek során, hosszú távon a kínai stratégia érvényre jutásával kell számolnunk. Peking pedig a realitások talaján maradva, egy ideig minden bizonnyal megelégszik a dél-kínai-tengeri pozícióinak konszolidálásával, egyúttal fenntartva az amerikai beavatkozás kockázatának Washington számára elviselhetetlen következményének látszatát. 
ANNUAL REPORT TO CONGRESS Military and Security Developments Involving the People's Republic of China 2016. Office of the Secretary of Defense, 2016 April 26 http://www.defense.gov/Portals/1/Documents/pubs/ $2016 \% 20$ China\%20Military\%20Power\%20Report.pdf;

Broder, Jonathan: What China's New Missiles Mean for the Future of the Aircraft Carrier. In: Newsweek, 2/16/16 23.;

Clover, Charles: China parades 'carrier-killer' missile through Beijing. ft.com, September 3, 2015 http://www.ft.com/ cms/s/0/b94d907a-507a-11e5-b029 b9d50a74fd14.html?siteedition=intl\#axzz4IKnQXFpD;

Cropsey, Seth - McGrath, Brian - Walton, Timothy A: Sharpening the Spear: The Carrier, the Joint Force, and High-End Conflict. Policy Study, Hudson Institute, October 2015; https://s3.amazonaws.com/media.hudson.org/files/ publications/201510SharpeningtheSpearTheCarriertheJointForceandHighEndConflict.pdf;

DF-26 intermediate-range ballistic missile. armyrecognition.com, 12 February 2016 http://armyrecognition.com/china chinese_army_missile_systems_vehicles/df-26_intermediaterange_ballistic_missile_technical_data_sheet_ specifications_pictures_video_11202167.html;

DF-ZF (formerly WU-14) WU-14 Dong Feng-21D (DF-21D) /CSS-5 Mod 5 Anti-Ship Ballistic Missile (ASBM). GlobalSecurity.org http://www.globalsecurity.org/wmd/world/china/df-21d.htm;

Kazianis, Harry J: China's DF-26 Anti-Ship Ballistic Missile: What Does the Pentagon Really Think? In: The National Interest, May 18, 2016 http://nationalinterest.org/blog/the-buzz/chinas-df-26-anti-ship-ballistic-missile-what-doesthe-16260;

Erickson, Andrew S: Showtime: China Reveals Two ,Carrier-Killer' Missiles. In: The National Interest, Sept 3, 2015 http://nationalinterest.org/feature/showtime-china-reveals-two-carrier-killer-missiles-13769;

Farley, Robert: Should America Fear China's „Carrier-Killer” Missile? In: The National Interest, June 22, 2016 http:// nationalinterest.org/feature/should-america-fear-chinas-carrier-killer-missile-11321;

Guo, Renjie: China's anti-ship missiles YJ-12 and YJ-100 revealed. China Military Online, 2015. 02. 04. http://eng. chinamil.com.cn/news-channels/china-military-news/2015-02/04/content_6340222.htm;

Hendrix, Henry J: At What Cost a Carrier? Disruptive defense papers, Center for a New American Security, March 2013 4-5. http://www.cnas.org/files/documents/publications/CNAS\%20Carrier_Hendrix_FINAL.pdf;

Hendrix, Henry J: Retreat from Range. The Rise and Fall of the Carrier Aviation. Center for a New American Security, October 2015 51-61. http://www.cnas.org/sites/default/files/publications-pdf/CNASReport-CarrierAirWing-151016. pdf;

Kazianis, Harry J: KAZIANIS: China's carrier-killer missile. In: Washington Times, October 31, 2013 http://www. washingtontimes.com/news/2013/oct/31/kazianis-chinas-carrier-killer-missile/;

Klemensits Péter: Kína építkezései a Spratley-szigeteken. A dél-kínai-tengeri konfliktus egy újabb fejezete. In: Honvédségi Szemle 2016, 144. évf, 4. sz. 56-63.;

Majumdar, Dave: Here Is Why the US Military Is Not In Panic Mode Over China's Carrier-Killer Missiles. Tiananmen's Tremendous Achievements, June 20, 2016 https://tiananmenstremendousachievements.wordpress. com/2016/06/22/23884/;

Mizokami, Kyle: The future of America's aircraft carriers? Floating drone factories. In: The Week, 21 April, 2016 http:// theweek.com/articles/619455/future-americas-aircraft-carriers-floating-drone-factories;

Wortzel, Larry M: The Dragon Extends its Reach: Chinese Military Power Goes Global. Potomac Books, Dulles, 2013; Yee, Chan Kai: China's 5 Anti-ship Missiles US Has No Effective Defense for 10 Years. Tiananmen's Tremendous Achievements, June 30, 2016 https://tiananmenstremendousachievements.wordpress.com/2016/06/30/chinas-5anti-ship-missiles-us-has-no-effective-defense-for-10-years/;

Yee, Chan Kai: Volley of China's DF-21D Missiles Kills US Aircraft Carrier at Low Cost. Tiananmen's Tremendous Achievements, June 6, 2016 https://tiananmenstremendousachievements.wordpress.com/tag/df-21d/.

\section{JEGYZETEK}

1 Shao Yongling ezredes, a kínai rakétaerő parancsnoki akadémiájának tisztje elismerte, hogy ez volt az első alkalom, amikor a nyilvánosság a valódi típusszámok feltüntetésével láthatta a rakétát.

2 A taiwani-szorosban végrehajtott kínai rakétakísérletekre válaszul az Egyesült Államok két repülőgép-hordozó csapásmérő csoportot küldött a térségbe, amelynek következtében Kína a Taiwannal szembeni erőszakos politikájának módosítására kényszerült, belátva, hogy az USA haditengerészetével nem veheti fel a versenyt még a saját partjai mentén sem.

3 Kazianis, Harry J: KAZIANIS: China's carrier-killer missile. In: Washington Times, October 31, 2013 http://www.washingtontimes. com/news/2013/oct/31/kazianis-chinas-carrier-killer-missile/ (Letöltés dátuma: 2016. 05. 30.) Chen Bingde tábornok a kínai Népi Felszabadító Hadsereg későbbi vezérkari főnöke csupán 2011-ben ismerte el hivatalosan a DF-21D kifejlesztését.

4 DF-ZF (formerly WU-14) WU-14 Dong Feng-21D (DF-21D) /CSS-5 Mod 5 Anti-Ship Ballistic Missile (ASBM). GlobalSecurity.org http:// www.globalsecurity.org/wmd/world/china/df-21d.htm (Letöltés dátuma: 2016. 05. 30.)

5 Kazianis, Harry J.
6 Clover, Charles: China parades 'carrier-killer' missile through Beijing. ft.com, September 3, 2015 http://www.ft.com/cms/s/0/b94d907a507a-11e5-b029-b9d50a74fd14.html?siteedition=int|\#axzz4IKnQXFpD (Letöltés dátuma: 2016. 05. 30.)

7 DF-ZF (formerly WU-14) WU-14 Dong Feng-21D (DF-21D) /CSS-5 Mod 5 Anti-Ship Ballistic Missile (ASBM).

8 Yee, Chan Kai: Volley of China's DF-21D Missiles Kills US Aircraft Carrier at Low Cost. Tiananmen's Tremendous Achievements, June 6, $2016 \mathrm{https} / / /$ tiananmenstremendousachievements.wordpress.com/tag/ df-21d/ (Letöltés dátuma: 2016. 05. 30.)

9 Kazianis, Harry J.: China's DF-26 Anti-Ship Ballistic Missile: What Does the Pentagon Really Think? In: The National Interest, May 18, $2016 \mathrm{http}: / /$ nationalinterest.org/blog/the-buzz/chinas-df-26-anti-shipballistic-missile-what-does-the-16260

(Letöltés dátuma: 2016. 05. 30.)

10 DF-26 intermediate-range ballistic missile. armyrecognition.com, 12 February 2016 http://armyrecognition.com/china_chinese_army missile_systems_vehicles/df-26_intermediate-range_ballistic_missile technical data_sheet_specifications_pictures_video_11202167.html (Letöltés dátuma: 2016. 05. 30.) 
11 ANNUAL REPORT TO CONGRESS Military and Security

Developments Involving the People's Republic of China 2016. Office of the Secretary of Defense, 2016 April $26 \mathrm{http} / / / w w w . d e f e n s e . g o v /$ Portals/1/Documents/pubs/2016\%20China\%20Military\%20 Power\%20Report.pdf

(Letöltés dátuma: 2016. 05. 30.)

12 Yee, Chan Kai: China's 5 Anti-ship Missiles US Has No Effective Defense for 10 Years. Tiananmen's Tremendous Achievements, June 30, $2016 \mathrm{https} / / /$ tiananmenstremendousachievements.wordpress. com/2016/06/30/chinas-5-anti-ship-missiles-us-has-no-effectivedefense-for-10-years/

(Letöltés dátuma: 2016. 05. 30.)

13 Guo, Renjie: China's anti-ship missiles YJ-12 and YJ-100 revealed. China Military Online, 2015. 02. 04. http://eng.chinamil.com.cn/ news-channels/china-military-news/2015-02/04/content_6340222.htm (Letöltés dátuma: 2016. 05. 30.)

14 Yee, Chan Kai: China's 5 Anti-ship Missiles US Has No Effective Defense for 10 Years.

15 Yee, Chan Kai: China's 5 Anti-ship Missiles US Has No Effective Defense for 10 Years.

16 Guo, Renjie

17 Részletesebben lásd: Klemensits Péter: Kína építkezései a Spratley-szigeteken. A dél-kínai-tengeri konfliktus egy újabb fejezete. In: Honvédségi Szemle 2016, 144. évf, 4. sz. 56-63.

18 Az első szigetlánc Japántól kezdve, magában foglalja Okinavát és Taiwant, majd tovább húzódik a Fülöp-szigeteki és maláj partok mentén, behatárolva gyakorlatilag a Kelet- és Dél-kínai-tenger térségét.

A második szigetlánc a Filippínó-tengertől keletre, a Marshallszigetek - Guam - Palau vonalat jelenti. Wortzel, Larry M: The Dragon Extends its Reach: Chinese Military Power Goes Global. Potomac Books, Dulles, 2013: 49. o.

19 Anti-Access/Area Denial

20 A 2010-ben meghirdetett stratégiai irányvonal kezdetben a „Pivot” elnevezést viselte, de az utóbbi időkben inkább a „rebalance” megjelölés terjedt el.

21 Kínaiul: 杀手铜武器 Erickson, Andrew S: Showtime: China Reveals Two ,Carrier-Killer' Missiles. In: The National Interest, Sept 3, 2015 http:// nationalinterest.org/feature/showtime-china-reveals-two-carrier-killermissiles-13769

(Letöltés dátuma: 2016. 05. 30.)
22 Hendrix, Henry J: At What Cost a Carrier? Disruptive defense papers, Center for a New American Security, March 2013 4-5. http://www. cnas.org/files/documents/publications/CNAS\%20Carrier_Hendrix FINAL.pdf (Letöltés dátuma: 2016. 05. 30.)

23 A 2016-os adatok szerint a USS GERALD F. FORD teljes költsége eléri a 17,5 mrd dollárt, a fedélzetén lévő 6 mrd dollár értékủ repülögépek nélkül. Mizokami, Kyle: The future of America's aircraft carriers? Floating drone factories. In: The Week, 21 April, 2016 http:// theweek.com/articles/619455/future-americas-aircraft-carriersfloating-drone-factories (Letöltés dátuma: 2016. 05. 30.)

24 A DF-21D rakéta beszerzési ára két kínai szakértő szerint kb. 5-11 millió dollár között mozoghat. Hendrix: 6-8.

25 Hendrix 9.

26 Hendrix: 5-10 és Hendrix, Henry J: Retreat from Range. The Rise and Fall of the Carrier Aviation. Center for a New American Security, October 2015 51-61. http://www.cnas.org/sites/default/files/ publications-pdf/CNASReport-CarrierAirWing-151016.pdf (Letöltés dátuma: 2016. 05. 30.)

27 Yee, Chan Kai: Volley of China's DF-21D Missiles Kills US Aircraft Carrier at Low Cost.

28 Cropsey, Seth - McGrath, Brian - Walton, Timothy A: Sharpening the Spear: The Carrier, the Joint Force, and High-End Conflict. Policy Study, Hudson Institute, October 2015 https://s3.amazonaws.com/ media.hudson.org/files/blications/201510

SharpeningtheSpearTheCarriertheJointForceandHighEndConflict.pdf (Letöltés dátuma: 2016. 05. 30.)

29 Broder, Jonathan: What China's New Missiles Mean for the Future of the Aircraft Carrier. In: Newsweek, 2/16/16 23.

30 Majumdar, Dave: Here Is Why the US Military Is Not In Panic Mode Over China's Carrier-Killer Missiles. Tiananmen's Tremendous Achievements, June 20, 2016 https://tiananmenstremendousachievements. wordpress. com/2016/06/22/23884/ (Letöltés dátuma: 2016. 06. 28.)

31 AirSea Battle

32 Farley, Robert: Should America Fear China's „Carrier-Killer” Missile? In: The National Interest, June 22, 2016 http://nationalinterest.org/ feature/should-america-fear-chinas-carrier-killer-missile-11321 (Letöltés dátuma: 2016. 06. 28.)

33 Broder: 23?

\section{HM ZRÎNYI TÉRKÉPÉSZETI ÉS KOMMUNIKÂCIÓS SZOLGÁLTATÓ KÖZHASZNÚ NKFT.}

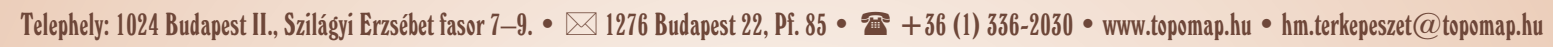

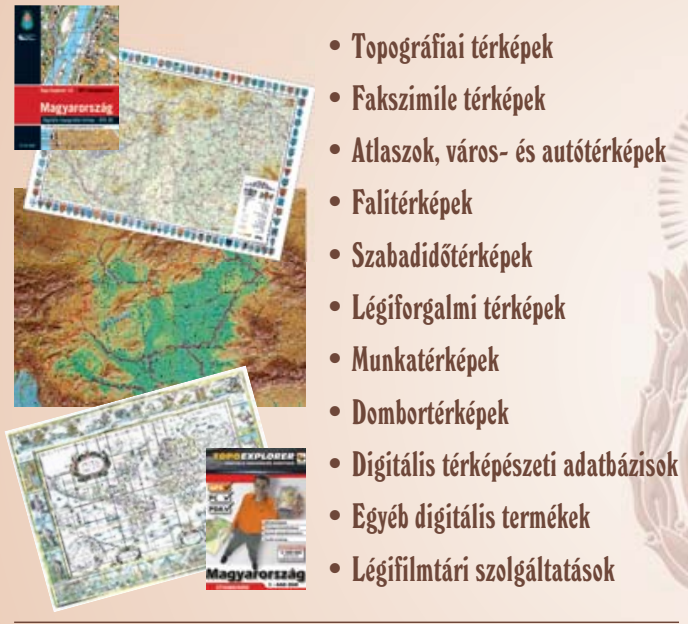

ÜGYFÉLSZOLGÁLAT ÉS TÉRKÉPBOLT:

1024 Budapest II., Fillér u. 14.

Fie +36 (1) 212-4540・uǵffelszolgalat@topomap.hu Nyitva tartás: hétfó-péntek 9.00-15.00
- PrePress - Nyomdai elókészités

- szövég-, grafika- és képfeldolgozás, kiadványszerkesztés

- ellenôrző nyomatok, digitális proofok elóállítása

- bel- és kiulltéri tablók, bannerek nyomtatása

- hagyományos és elektronikus montírozás, színrebontás

- nyomóformák elóállítása nyomdai filmról, illetve CTP-technológiával

- Gyorssokszorositás

- színes és fekete-fehér másolás/nyomtatás 330 x 487 mm méretig

- Press - Nyomtatás

- ofszetnyomtatás négy-, illetve hatszínnyomó gépeken, 89 x 126 cm méretig

- PostPress - Kötészeti feldolgozás

- feliiletnemesités fóliázással, laminálással 167 cm szélességig

- hajtogatás, spirálozás, sorszámozás

- összehordás, irkakészítés, ragasztókötés

- kasírozás, táblakészítés, aranyozás

- szortiment könyvkötészet

- Vákuumformázás

- vákuumformázó szerszámok, terepasztalok előállítása CNC-technológiával - vákuumformázás

$$
\text { NYOMDAI GYáRTÁSELőKÉSZITÉS: 芭 + 36 (1) 336-2035 }
$$

